\title{
Creating Shared Value by Combatting Corruption
}

\author{
Philip M. Nichols, University of Pennsylvania, USA
}

\section{Introduction}

Many people offer differing definitions of emerging economies; one salient way of understanding emerging economies is that they are experiencing profound change, particularly institutional change. Inexperience with and weaker accountability in institutions contributes to more frequent incidents of corruption, which is costly for local and transnational businesses. Businesses operating in emerging economies should consider the creating shared value strategy, a business strategy that increases profitability by improving the social context in which a business firm operates. Although fairly well known in some emerging economies, among North American and European business firms the creating shared value strategy has received little attention. A debate between Michael Porter and Mark Kramer (2011) and Andrew Crane and others (2014), for example, treats the creating shared value strategy as if it exists only in theory.

In emerging economies the creating shared value strategy is a reality. Implementing the strategy requires rethinking and refocusing goals so as to take into account unmet social needs, and is made easier by socially-oriented partners with shared interests. Difficulties in implement the strategy include difficulties in measurement and difficulties in finding a common language. This article, after explaining the creating shared value strategy, suggests that solutions to those difficulties are to be found by leveraging off of the existing global and local efforts to control corruption.

\section{Corporate Social Responsibility and Social Impact}

The creating shared value strategy explicitly deals with the intersections between a business firm and other aspects of society. It thus is sometimes confused with other undertakings in the same realm. It is helpful, therefore, to distinguish creating shared value strategies from similar undertakings.

The best known of these is corporate social responsibility. The phrase "corporate social responsibility" has become so overused as to have almost lost any meaning. At its roots, however, corporate social responsibility describes a business that acts as a mature and responsible member of society. This can manifest itself in a multitude of ways. A business firm might, for example, attempt to reduce its carbon footprint because it feels that that is what a responsible and mature member of society does, or for similar reasons might contribute to efforts to clean up a park shared by the local community. Ben \& Jerry's offers an interesting example of corporate social responsibility. The firm wears its social values on its sleeves; its website is peppered with comments such as "it's not just an environmental issue; it is an issue of social and economic justice," and "it's good for us to turn a shovel, lift a hammer or dip a paint brush to do some good in our local communities."

"Social impact" is a phrase that is becoming almost as popular as "corporate social responsibility," and is similarly at risk of losing meaning. At its heart social impact refers to the use of business skills, tools and experience to effectuate socially desirable goals rather than business goals. A non-profit, socially-oriented organization might do so, as when First Book utilizes business techniques to place books in the hands of children who otherwise would never get them. Non-profit organizations might work in concert with for-profit businesses, as when the National Trust for Historic Preservation jointly marketed with American Express to raise funds to restore the Statue of Liberty. Or it may be undertaken entirely by a for-profit business, as when Jesus Vizcarra Calderón utilized the extensive business experience he had accumulated in turning Corrales Vizcarra into one of Mexico's largest beef exporters to create and operate Salud Digna, a premiere healthcare facility for people of lesser means.

\section{Creating Shared Value}

The creating shared value strategy is similar to corporate social responsibility and to social impact in that it focusses on the intersection between business and the rest of society. It differs, however, in that it is a business strategy intended to contribute to the profit earned by a business. creating shared value is about the bottom line.

Creating shared value strategies recognize that business is embedded in society and business firms benefit from the many inputs provided by society, and that failures in society limit the extent to which a business firm can profit and grow. A creating shared value strategy enriches society in a targeted way, so as to make it possible for a business firm to profit and grow.

One example of a creating shared value strategy in an emerging economy is the work of AACE Food Processing \& Distribution Ltd., founded in Nigeria by Ndidi and Mezuo Nwuneli. AACE faced difficulties in expand- 
ing and even in maintaining production, largely because the substandard production methods in Nigeria resulted in sporadic supply and in foodstuffs that did not meet quality standards.

A conventional approach to these difficulties would be to either import foodstuffs from a more reliable source or to relocate to a country with access to stable supplies. The Nwuneli's instead invested time and money into improving agriculture in Nigeria's West and Central regions. Among other things, AACE organized educational workshops, helped provide credit and insurance, and organized coops. Significantly, the Nwuneli's did not tie participation in these programs to providing foodstuffs to AACE. They simply improved the quality of agriculture in Nigeria. As, however, the quality of agriculture in Nigeria improved, so too did the fortunes of AACE. AACE now has steady access to high quality foodstuffs, has a solid position in the Nigerian market, and is a respected exporter to European and North American markets.

\section{Implementing a Creating Shared Value Strategy}

Firms adopt creating shared value strategies to enhance their bottom line, but a creating shared value approach differs markedly from the conventional North American approach. The conventional approach seeks the easiest route to the lowest hanging fruit. Warren Buffett captured this approach in a letter to Berkshire Hathaway shareholders: "Easy does it. After 25 years of buying and supervising a great variety of businesses, Charlie and I have not learned how to solve difficult business problems. What we have learned is to avoid them. To the extent we have been successful, it is because we concentrated on identifying one-foot hurdles that we could step over rather than because we acquired any ability to clear seven-footers" (Buffett, 1990).

The creating shared value strategy takes on those seven-foot barriers, but attempts to reduce them to one-footers rather than to jump over them.

A study of successful implementation of creating shared value strategies found that among the most important factors for success are (1) restating goals around societal needs, (2) focusing efforts on defined unmet needs, (3) tracking value creation for the firm and for society, and (4) bringing in partners for mutual benefit. The same study also identified barriers to implementation of creating shared value strategies, including: (1) a longer time frame than conventional strategies, (2) difficulties in measuring social and firm benefits, (3) inadequate shared language encompassing a broad perspective, and (4) difficulties in understanding social needs (Pfizer, Bockstette, \& Stamp, 2013).

\section{Corruption and lts Costs}

Corruption can be defined as abuse or misuse of a position of power or trust for personal benefit rather than the purpose for which that power or trust was bestowed. Although not socially accepted anywhere, in many emerging economies corruption clearly constitutes part of the social context in which businesses are embedded. Indeed, corruption is identified as one of the top five impediments to business in more than half of the countries analyzed in the World Economic Forum's Competitiveness Index (2016), most of which are emerging economies.

Corruption imposes costs on an individual business. Studies have found that firms that pay bribes spend more time and money dealing with government than firms that do not. Corruption distorts the allocation of resources within a business firm, and is associated with decreased productivity and slower rates of market penetration; increases the cost of raising capital and decreases the share value of publicly traded firms; diminishes the ability of a business firm to form relationships with other firms; degrades the internal ethical climate of a firm, which can contribute to self-serving or dysfunctional behavior among workers; and creates legal liabilities, including the potential of imprisonment (Nichols, 2012).

More importantly, corruption inflicts extensive damage on the social context in which businesses are embedded. Corruption eviscerates society. Corruption retards economic growth, decreases rates of investment, increases inflation and depreciates currency. Corruption distorts public spending, which manifests itself in ways such as low quality infrastructure, inadequate education, ineffective healthcare, and unenforced environmental rules. Not surprisingly, there is also a strong relationship between corruption and mistrust of government and other institutions.

\section{Business Strategies to Deal with Corruption}

Current business activities seem to focus on costs and risks. Managers, understandably, want to reduce operational costs and want to avoid going to jail. Most if not all transnational firms have implemented internal programs to prevent violation of the law by people associated with the firm. Many large firms also train local suppliers, distributors, and other associated local firms in compliance, again for the purpose of avoiding secondary liability. Dell, for example, requires all suppliers to attest that they will comply with anticorruption laws and to participate in Dell's Supplier Engagement, Capability Building and Assessment Programs.

Some businesses do contribute to projects intended to control corruption. Siemens, as part of a settlement following its admission to paying bribes, has created a US\$100 million fund to support anticorruption projects. Funded projects include the Basel Institute on Governance and the International Anti-Corruption Academy. While these programs and projects might indirectly benefit Siemens, they are undertaken purely for their own merit.

\section{Corruption Control as a Creating Shared Value Strategy}

Although not yet adopted by transnational firms, corruption control offers several attractive features with respect to creating shared value strategies. The attractiveness of such a strategy can be illustrated by returning to the practices that contribute to successful implementation of a creating shared value strategy. 
One aspect of a successful implementation is understanding and defining societal needs. This is not always simple; CEMEX, for example, sent teams of engineers, anthropologists, and sociologists across Mexico for over a year to define the social needs of rural persons. In the case of corruption, however, a business firm can leverage off of a great deal people and institutions, including the World Bank, the Organization for Economic Cooperation and Development, and dozens of regional organizations.

Accurate measurement and tracking also contribute to successful implementation of a creating shared value strategy. With respect to business operations, this is relatively easy. Businesses have had centuries to develop and refine such measurement, and measurement and tracking are the focus of many business school curriculums. Moreover, measurement has for the most part a common denominator-units of currency. of detailed research that has been conducted by a great variety of

countries. Those chapters represent only the tip of the iceberg. No comprehensive catalogue of local anticorruption organizations exists, but the number of such organizations could be in the thousands.

\section{Difficulties in Implementing a Creating Shared Value Strategy}

The problems in implementing a creating shared value strategy do exist with respect to corruption, and a firm should understand those problems. Most seriously, creating shared value strategies require longer time horizons than some western business firms, particularly publicly traded firms facing quarterly pressure from stock analysts, can contemplate. Very little research explores the timeframe for controlling corruption. Some believe that corruption control follows a "tipping point" path: progressing slowly until reaching some tipping point, after which incidents of corruption sharply decrease. It is unlikely, however, that any investment in improving the condition of the social context in which a business firm is embedded will yield immediate returns.

Creating shared value strategies also suffer from the bias toward increasing revenue rather than reducing costs. Improving social conditions

The same cannot generally be said for socially desirable goals. Far less effort has been put into developing social measurement techniques, and there is no common denominator to make comparison easy and meaningful. Society cannot even agree upon definitions for objectives such as the general healthfulness of a population, much less agree on measurement. A great number of social needs that might otherwise be fertile ground for a creating shared value strategy simply cannot be measured.

Corruption does not suffer that difficulty. Corruption is without question difficult to monitor and track, but useful tools have emerged over the last twenty years, including Transparency International's Corruption Perceptions Index, the Global Economic Forum's Competitive Index, and risk analysis measures developed by consulting firms.

Finally, successful implementation of a creating shared value strategy often turns to local partners for mutual benefit. Unilever Hindustan, for example, turned to local organizations dedicated to empowering village women when Unilever was trying to identify women with the potential to succeed as retail sellers when Unilever implemented its shakti program. Unilever benefitted in not having to replicate (if it could) the detailed local knowledge that the empowerment organizations had developed over a period of years, and the goals of the local empowerment organizations were furthered using Unilever's resources and business opportunities.

The realm of corruption offers a rich variety of potential partners. Around the world, people have tired of corruption and have organized against it. Transparency International has chapters in more than one hundred with respect to corruption will reduce the cost to a firm of engaging in business, but in some circumstances it may not create new lines of revenue, nor will a manger be able to point to a discrete revenue stream that flows from implementation of the strategy. In many circumstances, however, a firm will be able to win bids or clients that it could not have been able to win in a corrupt system, because that firm will now be able to compete in a transparent way based on cost and quality rather than on the basis of opaque connections and underhanded bribes.

\section{A Useful Strategy}

Corruption is not unique to emerging economies, but the heightened level of corruption in many emerging economies cannot be denied. Firms working in emerging economies should not avoid honest evaluation of the extent to which corruption imposes costs and will at some point limit growth. Because corruption constitutes part of the broad social context, a creating shared value strategy targeting corruption may be the most effective response.

The work of international and local anticorruption organizations creates an avenue whereby firms can implement such strategies. Firms can learn from existing research on the social context of corruption in their environment, and can borrow existing measurement tools. Firms can utilize the social goals and metrics created by those organizations. Most importantly, firms can leverage existing anticorruption efforts and can work with experienced organizations to improve the social and business environment. 


\section{References}

Buffett, W. 1990. Letter to the shareholders of Berkshire Hathaway Inc. http://www.berkshirehathaway.com/letters/1989.html.

Crane, A., Palazzo, G., Spence, L. J., \& Matten, D. 2014. Contesting the value of "Shared Value." California Management Review, 56(2): 130-153.

Nichols, P. M. 2012. The business case for complying with bribery laws. American Business Law Journal, 49(2): 325-368.

Pfizer, M., Bockstette, V., \& Stamp, M. 2013. Innovations for shared value. Harvard Business Review. 91(9): 100-107.

Porter, M. E., \& Kramer, M. R. 2011. Creating shared value. Harvard Business Review 89(1/2): 62-77.

World Economic Forum. 2016. Global Competitiveness Report. http:// www3.weforum.org/docs/gcr/2015-2016/Global_Competitiveness_Report_2015-2016.pdf.

Philip M. Nichols (nicholsp@wharton.upenn.edu) is a Professor of Legal Studies and Business Ethics at the Wharton School of the University of Pennsylvania. He has worked with organizations in more than a dozen countries on issues of corruption, and currently serves as the Co-Chair of the Anti-Corruption Law Interest Group of the American Society of International Law, and as the President of the Academy of Legal Studies in Business. 